\title{
Law analysis of birth registration based on the biological father's recognition
}

\author{
E.P. Handayani, Z. Arifin*, S. Firdaus \& L. Dwijayanto \\ Kadiri Islamic University, Kediri, Indonesia
}

\begin{abstract}
This study aimed to analyze the importance of the biological father's recognition of children in birth registration reviewed from civil law and the procedure of a biological father recognizing a natural child that had been recorded in the civil registry administratively based on the marriage certificate. The problem formulation in this study was answered with normative legal research. The results showed that the recognition of biological fathers to children in birth registration was very important because it was very influential in the life of the child today and in the future. The procedure conducted by the biological father in acknowledging the biological child that had been recorded on the civil registry in the sequence was that the applicant filed a lawsuit to the court with the conditions that have been determined, prepared evidence in the form of DNA test results, and proposed two witnesses to provide information and strengthen the lawsuit.
\end{abstract}

Keywords: natural child, recognition, birth certificate

\section{INTRODUCTION}

The presence of a child in a normal marriage is one of the dreams for every married couple. But in reality, there are some people who throw away their own children to cover up disgrace for their families. The disposal was carried out because the child born was an out-of-wedlock child who was not justified in the religious and ethical tenets that prevail in society (Witanto, 2012). The status of the child in family law is grouped into two kinds, namely legal children and natural children (an out-of-wedlock child). The legality is stipulated in Law Number 1 of 1974 Article 42 which reads "A legitimate child is a child born in or as a result of a lawful marriage." A legitimate child has a perfect civil relationship with his parents (Afandi, 1982).

The civil relations in question include the right of nasab (lineage) of children connected to the father (in Islam), the right to fulfill the living from parents to children, the right to care and education, the right to inherit each other, the right of marriage for the father of daughters, and other civil rights (Hadikusuma, 2013). The natural child is a child born outside of a legal marriage between his parents.

An illegitimate child has only a civil relationship with his mother and his mother's family. The child has no legal relationship with his father because legally both religious law and national law he has no blood relation with the man who is his biological father. The child out-of-wedlock does not obtain the material and moral rights that should be obtained by a child from his father, such as the right to care, the right to a living, the right to marry for the daughter, and the right to inherit from each other in the event of death.

${ }^{*}$ Corresponding Author 
In principle from a biological point of view, it is impossible for a child not to have a father. Therefore, for the sake of the law concerning all consequences in the field of inheritance, citizenship, guardianship, and so on, there needs to be recognition and ratification of children so as to create a new civil legal relationship (Situmorang \& Sitanggang, 1991). There are several studies that have studied the problem, among others: Critical Study on Child Recognition Institute (Critical Study Between Islamic Law and Positive Law), conducted by Ahmad Darbi B; The Court's Viewpoints on the Decision of Child Foster Proposals conducted by Sirajuddin S; and The Position of Natural Child: Analysis of the Decision of the Constitutional Court Number 46/PUUVIII/2010 concerning Material Test of Article 43 Paragraph 1 of Law Number 1 Year 1974 concerning Marriage by Muhamad Arifin. However, the study has not examined the importance of child recognition by biological fathers in depth. Therefore, this study aimed to analyze the importance of the biological father's recognition of children in the recording of birth and the procedure of a biological father to recognize a biological child that had been recorded in the civil registry administratively based on the marriage book.

\section{METHODS}

To answer research questions, this study used normative legal research methods. Normative juridical methods were carried out by document studies to study existing norms or laws and regulations related to the status and rights of children and recognition of children (Soekanto \& Mamudji, 2004; Marzuki, 2011). The primary legal sources used are the Constitution of the Republic of Indonesia Year 1945, Law Number 1 of 1974 concerning Marriage, Law Number 23 of 2002 concerning Child Protection, the Book of Criminal Law, a Compilation of Islamic Law, and the Book of Civil Law. Secondary sources include official documents, books, research results in the form of reports, journals, opinions, and legal opinions.

\section{RESULTS AND DISCUSSION}

\subsection{The importance of biological father recognition for the child}

Based on the decision of the Constitutional Court Article 43 paragraph (1) of the Marriage Law that stated, "The natural child has a civil relationship with his mother and his mother's family and with the man as his father which can be proven based on science and technology and/or other evidence according to the law has a blood relationship including civil relations with his father's family." So, the natural child has only a civil relationship with his mother and his mother's family only.

The natural child has no relationship with his father so has no rights and obligations to his father, therefore the natural child has legally required recognition to create a civil relationship between a natural child and the father as a parent. Article 280 of the Civil Law stated that "By committing an act of confession to a natural child, a civil relationship has emerged between the child, and his father or mother".

According to the applicable civil law in Indonesia, the determination of a child's origin can be made by voluntary recognition and implemented recognition. Voluntary recognition of a child is a statement as determined in civil law that a mother and father or mother admit a child born to a mother is a true child from the result of their biological relationship and that the relationship is not in a valid marital bond, and not because of adultery. While the implemented confession is a confession that occurred because of the judge's ruling in a lawsuit of the origin of a child.

This is related to Article 287 paragraph (2) of the Civil Law which stated that if one of the crimes as mentioned in article 285 to 288, article 294, or article 322 of the Criminal Law, then the crime can be submitted to the court (Prodjodikoro, 1983). The judge can determine that the evil-doer is the rightful father of a child born of evil deeds based on strong evidence. 
Children born from adultery are not allowed to be recognized by the person who commits adultery unless there is a dispensation from the President as stipulated in Article 283 jo 273 of the Civil Law. According to this provision, children born from adultery cannot be forced to confess to the man who fertilized them. It is based on the principle of civil law which determines that the law of marriage must respect the provisions and norms that apply in society.

Article 250 of the Civil Law also stated that "Every child born or raised during marriage obtains the husband as his father." This recognition can be done by a deed made by employees of the Population and Civil Registration Department and must be recorded in the child's birth certificate (Supramono, 1998). Recognition is important because it causes legal consequences in the form of status for children outside marriage and civil relations between the child and the father or the mother who recognizes it as stipulated in Article 280 of the Civil Law which stated: "With the recognition made against a natural child, a civil relationship arises between the child, father, or mother".

As a result of the legal recognition of natural children, there are at least two legal consequences. First, the recognized natural child can use his surname. Second, the child has the right to bequeath either from the father or the mother who admits it. However, under certain circumstances, the confession does not cause a complete result.

It depends on when the confession is made and who admits it. If the confession is done outside of marriage then the confession has a complete effect. However, if the confession is done throughout the marriage of the mother and her husband (not the biological father of the child), then the child outside the recognized marriage is only entitled to use the name of his father (mother's husband/juridical father) alone without the right to inherit from the parent who admits it.

The importance of recognition by the biological father or determination of the origin of the child by the court has legal consequences in the form of legal status, nasab (lineage), and other civil relations between the child and his parents, so that between the child and his parents there is amahram relationship, guardians of marriage, mutual inheriting, the obligation of parents to provide a living, finance the education of the child, and others. Similarly, children are obliged to respect and be dutiful to parents and others. In other words, the child has a civil relationship with his parents who authorize him (admit it) especially the civil relationship with the father.

\subsection{The procedure of biological father to admit a natural child that has been recorded in the civil registry based on the marriage certificate}

Recognition of biological fathers to children in birth registration is reviewed from various sides is very important to do. From a legal point of view, recognition in the recording of birth implies the future of the child as well as the identity of the child. A child must know its origin by the determination of the law. However, this recognition is also vulnerable to cause problems, if in the future the biological father of the child wants to admit the child.

The problem is related to the birth certificate that the child already has. When the confession is carried out throughout the marriage of the mother and her husband, as a result the child's birth certificate states that the father is the husband of his mother (juridical father). This happens because the basis of making a birth certificate of them is a marriage certificate either from the Office of Religious Affairs or Civil Registry Agency. On the basis of this issue, it is important to conduct a study related to the procedure or legal steps that can be taken by the biological father when the child has a birth certificate stating that he is the son of his mother's husband (juridical father).

In Article 281 of the Civil Law, it is stated that the way to recognize a natural child, namely in the birth certificate of the child concerned and in the marriage certificate there is. In addition to the way of confession, there are other ways to recognize natural children. In Article 281 Paragraph (2) of the Civil Law, it is stated that the recognition can be made by a certificate made by employees of the Population and Civil Registration Department and must be recorded in the current birth register and subsequently the recognition is recorded in the minutes of the birth certificate of the child concerned. This recognition is made to a child who has been recorded as an out-of-wedlock child in 
the birth register at the Civil Registry Agency (Subekti, 1995). While the minutes of the certificate is the original deed in the bundle of deeds in the Civil Registry Agency, which is approved by the reporting, witnesses, and officials of the Civil Registry Agency.

Article 55 of the Civil Law confirms that the origin of a child can only be proven by the existence of an authentic birth certificate that has been issued by the authorized official (Abdul, 1997). If the deed does not exist, then the court will hold a closure on the child's origin after a thorough examination based on the evidence that has been qualified. Based on the provisions of the court, the institution of the birth registrar in the legal area of the court concerned issued a birth certificate for the child concerned.

The case of determining the origin of the child including the volunteer case, therefore, in the examination of the case of determining the origin of the child by confession, which must be proven is the terms of recognition as described above, not the correctness of the confession (Syarifuddin, 2006). According to article 287 of the Civil Law, investigating the question of who is the father of a child is prohibited. However, in article 288 of the Civil Law it is stated that investigating the question of who is the mother of a natural child is allowed and, in this case, the out-of-wedlock child must be proven that he is the child born by a mother he mentioned.

According to Article 272 of the Civil Law, every out-of-wedlock child except those born of adultery or desecration of blood, if the father and mother carry out the marriage, then the child becomes a legal child if the father and mother before carrying out the marriage admit it according to the provisions of the Law or the recognition are carried out in a separate deed. In article 280 of the Civil Law, it is stated that with the recognition of a child outside of marriage by the father and mother, the status of the child is valid as other legitimate children (Ustman, 1969).

But this recognition is something different in nature than legitimation. By recognition of a child, it does not become a legitimate child. The natural child, then becomes a legal child, if both parents then marry, after they recognize the child, or if the confession is made in the marriage certificate itself as stipulated in Article 272 of Civil Law (Satrio, 1991; Subekti, 1995). The certainty of a child is really the son of his father is certainly difficult to obtain. In this connection, the law determines and stipulates a grace period of 300 days and the shortest period of 180 days.

To obtain the status of the relationship between father, mother, and child born out of wedlock, the child must be recognized by the father and mother. The confession must be done by authentic deed, expressly, and should not be done in a way that is concluded only. According to Article 224 Paragraph (1) of the Civil Law, the recognition of children outside marriage is null and void if done in some circumstances. First, it is recognized by the man that it is forbidden to marry the mother of the child. Second, a husband who has been married more than 306 days before the birth of a child. Third, a man who is not yet 18 years old, unless the confession occurs at the wedding ceremony. Fourth, without prior consent from the child's mother during her. Fifth, without the prior written consent of the child if he is an adult.

The procedure to change birth certificate after the issuance of the Constitutional Court Decision Number 46/PUUVIII/2010 is as follows. First, the biological father must sue the parents of both the father and the mother who have recognized the natural child as his biological child and have had the birth certificate. Biological fathers must be able to prove it by DNA testing, witnesses who strengthen it, as well as other evidence that strengthens including electronic evidence if any. Second, there are two possibilities that the lawsuit is granted or the lawsuit rejected by the judge. If the lawsuit is granted then the verdict is taken to the Population and Civil Registration Department accompanied by a child's birth certificate. The last step, the Population and Civil Registration Department is to change the record by making a marginal note in the birth certificate because the certificate is made and issued only once by the state.

Based on the above problems, researchers recommend that the Population and Civil Registration Department should register a birth certificate not based on the marriage certificate but based on a birth certificate from a midwife or hospital that has her father's name. In addition, so that the child is not disturbed mentally because he has two fathers who are not the same on his birth certificate, then the first birth certificate needs to be declared missing and then issued a new birth certificate with the name of the biological father. The Office of Religious Affairs at the time of the couple's 
marriage should add a condition or certificate from the public health center or local hospital that the bride-to-be is not pregnant.

\section{CONCLUSIONS}

The recognition of biological fathers to children in the birth registry is very important because the recognition is very influential in the life of the child today and the future, especially related to the civil relationship between the child and the father. Confession can be done in four ways. First, it is recorded in the child's birth certificate. Second, it is recorded in the marriage certificate of the father and mother if both are married. Third, it is recorded in the nature of the deed made by the civil registry officer which is then recorded in the birth list according to the date of the making of the deed, then recorded in the birth certificate of the child. Fourth, it is recorded in another authentic deed. In this case, each interested person may demand that this confession be recorded on the child's birth certificate. The legal step of recognition of biological fathers to natural children who already have a birth certificate with juridical parents there are three steps. First, file a lawsuit against the juridical parents. Second, prepare evidence in the form of DNA test results and file two witnesses to testify and strengthen the lawsuit. After that, if the lawsuit is accepted, the Population and Civil Registration Department makes changes to the registrar by making a marginal note in the birth certificate on the basis of the verdict and birth certificate submitted by the biological father.

\section{REFERENCES}

Abdul, A. 1997. Ensiklopedi Hukum Islam. Jakarta: PT. Ichtiar Baru Van Hoeven.

Afandi, A. 1982. Hukum waris, hukum keluarga, hukum pembuktian. Jakarta: Rineka Cipta,

Arifin, M. 2017. Kedudukan anak luar kawin: analisis Putusan Mahkamah Konstitusi Nomor 46/PUUVIII/2010 Tentang Uji Materi Terhadap Pasal 43 Ayat 1 UU Nomor 1 Tahun 1974 Tentang Perkawinan. Ahkam 5(1): $117-137$.

Darbi, B. A. 2018. Telaah kritis tentang lembaga pengakuan anak (studi kritis antara hukum Islam dan hukum positif). Al-Bayyinah 2(1): 91-108.

Hadikusuma, H. 2013. Metode pembuatan kertas kerja skripsi ilmu hukum. Bandung: Mandar Maju.

Marzuki, P.M. 2011. Penelitian hukum. Jakarta: Kencana Prenada Media Group.

Prodjodikoro, R.W. 1983. Hukum warisan di Indonesia. Bandung: Sumur Bandung.

Satrio, J. 1991. Hukum harta perkawinan. Bandung: PT Citra Aditya Bakti.

Sirajuddin, S. 2010. Sudut pandang pengadilan terhadap putusan kuasa asuh anak. Mimbar Hukum dan Peradilan. Jakarta: Pusat Pengembangan Hukum Islam dan Masyarakat Madani (PPHIMM).

Situmorang, V.M. \& Sitanggang, C. 1991.Aspek hukum akta catatan sipil di Indonesia. Jakarta: Sinar Grafika. Soekanto, S. \& Mamudji, S. 2004. Penelitian hukum normatif. Jakarta: PT. Raja Grafindo Persada.

Subekti. 1995. Pokok-pokok hukum perdata. Jakarta: PT. Intermasa.

Supramono, G. 1998. Segi-segi hubungan luar nikah. Jakarta: Djambatan.

Syarifuddin, A. 2006. Hukum perkawinan Islam di Indonesia antara fiqih munakahat dan undang-undang perkawinan. Jakarta: Prenata Media.

Ustman, F. 1969. Al figh al-Islamy wa tathawwur. Kuwait: Darul Kuwaitiyyah.

Witanto, D.Y. 2012. Hukum keluarga (hak dan kedudukan anak luar kawin, pasca keluarnya putusan Mahkamah Konstitusi tentang uji materiil UU Perkawinan). Jakarta: Prestasi Pustaka. 